\author{
Olga Bobrzyńska ${ }^{a)}$ \\ (D) https://orcid.org/0000-0002-5212-3112
}

\title{
Miejsce zwykłego pobytu dziecka - uwagi na tle wyroków Trybunału Sprawiedliwości Unii Furopejskiej z dnia 28 czerwca 2018 r. (C-512/17) oraz z dnia 17 października 2018 r. (C-393/18 PPU)
}

\begin{abstract}
In cases C-512/17 and C-393/18 PPU, the national courts raised doubts as to the significance of the circumstances that should be taken into account in determining the habitual residence of a child. In particular the issue was whether the child's physical presence is a prerequisite in order to recognize that a child has his habitual residence in the country concerned. In its judgment of 17 October 2018, the Court of Justice found that a child must be physically present in a Member State in order to be regarded as habitually resident in that Member State. The parent's intention cannot be assigned a decisive role. The arguments in this respect are consistent with the interpretation of the concept of habitual residence laid out in the earlier judgment of 28 June 2018, in which the Court of Justice connected the habitual residence of the child with the place where the centre of that child's life is actually situated, and not with the place where the child would have lived in accordance with the plans of one of the parents. The Court's interpretation can be attributed to the so-called combined model of determining a habitual residence by looking for child's centre of interest, taking into account a number of circumstances, including the intention of parents with parental responsibility. Physical presence has rightly been recognized as a necessary condition for establishing jurisdiction under Regulation No 2201/2003 based on habitual residence.
\end{abstract}

Keywords: habitual residence of a child, grounds of jurisdiction, Regulation Brussels II bis

a) Dr, Uniwersytet Jagielloński. 


\section{Uwagi wstępne}

W unijnych normach kolizyjnych i jurysdykcyjnych dla spraw rodzinnych i opiekuńczych łącznik zwykłego pobytu stanowi podstawowy łacznik osobowy ${ }^{1}$. Jego stosowanie $\mathrm{w}$ normach jurysdykcyjnych ujednolicanych $\mathrm{w}$ ramach współpracy międzynarodowej na potrzeby ustalenia jurysdykcji w sprawach dotyczących odpowiedzialności rodzicielskiej ma długa tradycję. Poczatki wykorzystania kryterium miejsca zwykłego pobytu $\mathrm{w}$ dziedzinie szeroko rozumianego prawa prywatnego międzynarodowego łączą się z pracami Haskiej Konferencji Prawa Prywatnego Międzynarodowego nad regulacja kolizyjna w sprawach opieki nad małoletnimi ${ }^{2}$. Na forum Haskiej Konferencji zrezygnowano z wprowadzenia znanego i rozpowszechnionego $\mathrm{w}$ prawach krajowych pojęcia zamieszkania na rzecz kryterium miejsca zwykłego pobytu. W ten sposób chciano uniknąc problemów związanych ze zróżnicowaną treścią pojęcia zamieszkania na gruncie praw krajowych, w tym stosowaniem konstrukcji prawnych w postaci zamieszkania pochodnego dziecka od rodziców/opiekunów $^{3}$. W pracach Haskiej Konferencji założono, że ustalenie miejsca zwykłego pobytu obejmuje ustalenie i ocenę okoliczności faktycznych

${ }^{1}$ Rozporządzenie Rady (WE) nr 2201/2003 z dnia 27 listopada 2003 r. dotyczące jurysdykcji oraz uznawania i wykonywania orzeczeń w sprawach małżeńskich oraz w sprawach dotyczących odpowiedzialności rodzicielskiej, uchylające rozporządzenie (WE) nr 1347/2000. Dz.Urz. UE L nr 338 z dnia 23.12.2003 r. Polskie wydanie specjalne, rozdz. 19, T. 6, s. 243, sprostowanie: Dz.Urz. UE L nr 70 z dnia 14.03.2009 r., s. 19—47. Rozporządzenie Bruksela II bis zastąpiło rozporządzenie Rady (WE) nr 1347/2000 z dnia 29 maja 2000 r. w sprawie jurysdykcji, uznawania i wykonywania orzeczeń w sprawach małżeńskich i w sprawach dotyczących odpowiedzialności rodzicielskiej za dzieci obojga małżonków; rozporządzenie Rady (WE) nr 4/2009 z dnia 18 grudnia 2008 r. w sprawie jurysdykcji, prawa właściwego, uznawania i wykonywania orzeczeń oraz współpracy w zakresie zobowiązań alimentacyjnych. Dz.Urz. UE L nr 7 z dnia 10.01.2009 r., s. 1-21; rozporządzenie Rady nr 1259/2010 z dnia 20 grudnia 2010 r. w sprawie wprowadzenia w życie wzmocnionej współpracy w dziedzinie prawa właściwego dla rozwodu i separacji prawnej. Dz.Urz. UE L nr 343 z dnia 29.12.2010 r., s. 10 i n.

${ }^{2}$ Więcej na temat genezy pojęcia „miejsce zwykłego pobytu” i jego wykorzystania w pracach Haskiej Konferencji Prawa Prywatnego Międzynarodowego zob.: M.H. van Hoogstraten: La codification par traités en droit international privé dans le cadre de la Conférence de la Haye. „Académie de Droit International de la Haye, Recueil des cours" [dalej: RCADI] 1969, T. 122, (1967 III), s. 337-425 ; L.I. de Winter: Nationality or domicile: the present state of affairs. RCADI 1970, T. 128 (1969 III), s. 347-503; A. Bucher: La famille en droit international prive. RCADI 2000, T. 283, s. 9-186; O. Bobrzyńska: Zwykty pobyt w konwencjach Haskiej Konferencji Prawa Prywatnego Międzynarodowego. „Kwartalnik Prawa Prywatnego” 2019, z. 2, s. 417-466.

${ }^{3}$ Zob. Protokót nr 8, in: Actes de la Deuxième Conférence de la Haye. La Haye 1894, s. 94. 
świadczacych o integracji rodzinnej i społecznej dziecka w danym miejscu. Miejsce zwykłego pobytu ma stanowić rzeczywisty ośrodek życiowy dziecka (le centre effectif de la vie du mineur) ${ }^{4}$. Łacznik zwykłego pobytu stanowił przy tym początkowo łącznik subsydiarny $\mathrm{w}$ stosunku do łącznika obywatelstwa ${ }^{5}$, jednakże z czasem role te się zmieniły. Wypierając stopniowo łącznik obywatelstwa ${ }^{6}$, łącznik zwykłego pobytu stał się podstawowym łącznikiem w Konwencji o jurysdykcji, prawie właściwym, uznawaniu, wykonywaniu i współpracy w zakresie odpowiedzialności rodzicielskiej oraz środków ochrony dzieci z 1996 r. ${ }^{7}$ Miejsce zwykłego pobytu stanowi również kryterium wyznaczające zakres zastosowania Konwencji haskiej o cywilnych aspektach uprowadzenia dziecka z 1980 r. mającej na celu doprowadzenie do powrotu dziecka do państwa jego zwykłego pobytu oraz ochronę prawa do opieki i prawa do odwiedzin.

Obie kategorie spraw, dotyczące odpowiedzialności rodzicielskiej oraz powrotu bezprawnie uprowadzonego lub zatrzymanego dziecka, zostały objęte zakresem rozporządzenia Rady (WE) nr 2201/2003 z dnia 27 listopada 2003 r. dotyczącego jurysdykcji oraz uznawania i wykonywania orzeczeń w sprawach małżeńskich oraz w sprawach dotyczących odpowiedzialności rodzicielskiej, uchylającego rozporządzenie (WE) nr 1347/2000 (rozporządzenie Bruksela II bis). Przepisy rozporządzenia, w tym wprowadzenie kryterium miejsca zwykłego pobytu, były w dużej mierze inspirowane bezpośrednio konwencjami haskimi ${ }^{9}$. Miejsce zwykłego pobytu dziecka stanowi w rozporządzeniu podstawę jurysdykcji ogólnej w sprawach dotyczących odpowiedzialności rodzicielskiej ${ }^{10}$. Rozporządzenie uzu-

${ }^{4}$ Zob. W. von Steiger: Rapport explicatif, in: Actes et documents de la Neuvième session (1960). T. 4. Protection des mineurs. La Haye 1961, s. 14.

${ }_{5}^{5}$ Tak w konwencji haskiej dotyczącej uregulowania opieki nad małoletnimi z dnia 12 czerwca 1902 r. Dz.U. 1929, nr 80, poz. 596.

${ }^{6}$ Zob. rozwiązania konwencji o właściwości organów i prawie właściwym w zakresie ochrony małoletnich, sporządzonej w Hadze dnia 5 października 1961 r. Dz.U. 1995, nr 106, poz. 519 .

${ }^{7}$ Do konwencji przystąpiły 52 państwa, w tym wszystkie państwa członkowskie UE. Dz.U. z dnia 22 września 2010 r., nr 172, poz. 1158.

${ }^{8}$ Konwencja ta odniosła duży sukces pod względem liczby państw, które do niej przystapiły (obecnie państw tych jest 101). Dz.U. 1995, nr 108, poz. 528, sprostowanie: Dz.U. 1999, nr 93, poz. 1085.

${ }_{9}$ Zob. wyjaśnienie dot. przepisów sekcji 2. w projekcie rozporządzenia Bruksela II bis, Proposal for a Council Regulation concerning jurisdiction and the recognition and enforcement of judgments in matrimonial matters and in matters of parental responsibility repealing Regulation (EC) No 1347/2000 and amending Regulation (EC) No 44/2001 in matters relating to maintenance /COM/2002/0222 final. Dz.Urz. UE E nr 203 z dnia 27.08.2002 r., s. $155-178$.

${ }_{10}$ Przepis art. 8 rozporządzenia Bruksela II bis ustanawia jurysdykcję ogólną sądów państwa, w którym dziecko ma miejsce zwykłego pobytu w chwili wniesienia pozwu/ wniosku. 
pełnia ponadto mechanizmy konwencji haskiej z $1980 \mathrm{r}{ }^{11}$, w tym zawiera przepisy broniące przed automatyczną utratą jurysdykcji w związku ze zmiana miejsca zwykłego pobytu przez sądy państwa, w którym dziecko miało miejsce zwykłego pobytu przed jego bezprawnym uprowadzeniem lub zatrzymaniem. Miejsce zwykłego pobytu wyznacza zakres zastosowania rozporządzenia w relacjach z konwencją haską z 1996 r. Rozporządzenie Bruksela II bis ma pierwszeństwo, gdy miejsce zwykłego pobytu znajduje się $\mathrm{w}$ państwie członkowskim ${ }^{12}$ lub $\mathrm{w}$ państwie trzecim niebędącym stroną konwencji haskiej z $1996 \mathrm{r}$.

\section{Rodzaj okoliczności branych pod uwagę przy ustalaniu miejsca zwykłego pobytu dziecka}

W preambule rozporządzenia Bruksela II bis wskazano, że podstawy jurysdykcji zostały ustanowione zgodnie z kryterium bliskości, majacym służyć realizacji zasady dobra dziecka ${ }^{13}$. Odwołanie to ma charakter ogólny, dotyczy tak kryterium miejsca zwykłego pobytu jako podstawy jurysdykcji ogólnej, jak i wyjątków na rzecz innych podstaw jurysdykcji. Zasada dobra dziecka ma stanowić także motyw przewodni działań podejmowanych w sprawach rozpoznawanych na gruncie rozporządzenia ${ }^{14}$, co Trybunał Sprawiedliwości UE często podkreśla w swoim orzecznic-

${ }^{11}$ Artykuł 10 i 11 rozporządzenia Bruksela II bis.

${ }_{12} \mathrm{Z}$ wyjątkiem Danii. Artykuł 2 pkt 3 oraz art. 61 a rozporządzenia Bruksela II bis.

${ }^{13} \mathrm{~W}$ pkt. 12 preambuły rozporządzenia podkreślono, że podstawy jurysdykcji w sprawach odpowiedzialności rodzicielskiej ukształtowane sa zgodnie z zasadą dobra dziecka, w szczególności według kryterium bliskości. Jurysdykcję sprawują co do zasady sądy państwa członkowskiego miejsca zwykłego pobytu dziecka, z odstępstwem dla niektórych przypadków zmiany miejsca pobytu dziecka lub porozumienia zawartego między podmiotami odpowiedzialności rodzicielskiej. W pkt. 13 preambuły powołano się na interes dziecka, w imię którego, w ramach wyznaczonych rozporządzeniem, może nastąić przekazanie sprawy sądowi innego państwa członkowskiego, jeżeli ten jest lepiej umiejscowiony dla osądzenia sprawy.

${ }^{14}$ Nakaz działania z uwzględnieniem najlepszego interesu dziecka wynika z Karty praw podstawowych Unii Europejskiej (Dz.Urz. UE C nr 326 z dnia 26.10.2012 r., s. 391-407), do której odwołano się w pkt. 33 preambuły rozporządzenia (ma zmierzać do zapewnienia przestrzegania podstawowych praw dziecka określonych w art. 24 Karty praw podstawowych UE, przewidującym m.in., że we wszystkich działaniach dotyczacych dzieci, zarówno podejmowanych przez władze publiczne, jak i instytucje prywatne, należy przede wszystkim uwzględnić najlepszy interes dziecka). 
twie $^{15}$. Rola interesu i praw dziecka stanowi jeden z aspektów dyskusji nad wykładnią pojęcia miejsca zwykłego pobytu, który został przywołany w sprawie C-393/18 PPU, o czym będzie jeszcze mowa poniżej.

$\mathrm{Na}$ wzór praktyki Haskiej Konferencji ${ }^{16}$ w rozporządzeniu Bruksela II bis nie sformułowano definicji pojęcia zwykłego pobytu, wskazując, że ma ono charakter faktyczny i zadaniem sędziego jest ustalenie miejsca zwykłego pobytu dziecka w konkretnym przypadku ${ }^{17}$. Wskazówki na temat znaczenia przypisywanego pojęciu na gruncie rozporządzenia wynikają z orzecznictwa Trybunału Sprawiedliwości, który wypowiadał się w tej kwestii wielokrotnie. Trzon pojęcia stanowi określenie miejsca zwykłego pobytu dziecka jako „centrum życiowego”. Powiązanie dziecka z danym państwem ma wykazywać pewną integrację ze środowiskiem społecznym i rodzinnym ${ }^{18}$. Określenia te wymagają jednak dalszego wyjaśnienia ${ }^{19}$.

${ }_{15}$ Zob. pkt 43 wyr. Trybunału z dnia 27 października 2016 r. w sprawie C 428/15 i przywołane tam orzeczenia.

${ }_{16}$ Zob. P. Lagarde: Explanatory Report on the 1996 Hague Child Protection Convention. In: Proceedings of the Eighteenth Session (1996). T. 2. Protection of children. The Hague 1998, s. 553.

${ }_{17}$ Zob. wyjaśnienie do art. $10 \mathrm{w}$ projekcie rozporządzenia Bruksela II bis. $\mathrm{COM} / 2002 / 0222$ final. Definicja nie została również wprowadzona w przyjętym w dniu 25 czerwca 2019 r. rozporządzeniu Rady (UE) 2019/1111 w sprawie jurysdykcji, uznawania i wykonywania orzeczeń w sprawach małżeńskich i w sprawach dotyczących odpowiedzialności rodzicielskiej oraz w sprawie uprowadzenia dziecka za granicę. Dz.Urz. UE L nr 178 z dnia 2.07.2019 r., s. 1-115.

${ }_{18}$ Zob. pkt 42 wyr. Trybunału z dnia 28 czerwca 2018 r. w sprawie HR przy udziale: KO, Prokuratury Rejonowej Poznań-Stare Miasto w Poznaniu, C-512/17, http://curia. europa.eu.

${ }_{19}$ Łacznik zwykłego pobytu, z uwagi na jego szerokie wykorzystanie w normach kolizyjnych i jurysdykcyjnych ustanawianych na szczeblu krajowym i międzypaństwowym dla różnych zakresów spraw, jest przedmiotem wielu opracowań. W polskiej literaturze zob.: A. Mączyński: Statut personalny osób fizycznych. Refleksje „de lege lata” $i$,de lege ferenda”. W: „Leges Sapere”. Studia i prace dedykowane Profesorowi Januszowi Sondlowi w pięćdziesiata rocznice pracy naukowej. Red. W. Uruszczak et al. Kraków 2008, s. 305-323; P. Mostowik: Wtadza rodzicielska i opieka nad dzieckiem w prawie prywatnym międzynarodowym. Kraków 2014, s. 234-241; M. Świerczyński, w: „System Prawa Prywatnego". T. 20A: Prawo prywatne międzynarodowe. Red. M. Pazdan. Warszawa 2014, s. 232-236; M. Pilich: Zasada obywatelstwa w prawie prywatnym międzynarodowym. Warszawa 2015, s. 250-264; Idem: Eqczniki personalne osób fizycznych w prawie prywatnym międzynarodowym (zagadnienia wybrane). „Problemy Prawa Prywatnego Międzynarodowego” 2016, T. 19, s. 17-25. Za granica tematyka związana z łącznikiem zwykłego pobytu jest szeroko opracowana m.in. przez przedstawicieli doktryny niemieckiej. Zob.: D. Baetge: Der gewöhnliche Aufenthalt im Internationalen Privatrecht. Tübingen 1994; B. Rentsch: Der gewöhnliche Aufenthalt im System des Europäischen Kollisionsrechts. Tübingen, Mohr Siebeck, 2017. 
Należy zwrócić uwagę, że przy ustalaniu miejsca zwykłego pobytu dziecka pojawiaja się specyficzne problemy, które nie występuja przy ustalaniu miejsca zwykłego pobytu osoby dorosłej. Decyzję w sprawie miejsca pobytu dziecka podejmuja osoby sprawujące nad nim opiekę. Kategoria transgranicznych spraw dotyczących odpowiedzialności rodzicielskiej to sprawy delikatne, wynikające najczęściej ze sporu między rodzicami/opiekunami co do losów dziecka, w tym co do miejsca, w którym dziecko ma zamieszkać z jednym z rodziców. Potrzeba stwierdzenia miejsca zwykłego pobytu może zachodzić tuż po narodzinach dziecka.

Począwszy od wyroku w sprawie A z dnia 2 kwietnia 2009 r. ${ }^{20} \mathrm{w}$ orzeczeniach Trybunału pojawia się ogólne sformułowanie określające pojęcie zwykłego pobytu jako pojęcie autonomiczne na gruncie rozporządzenia, którego treść należy ustalić z uwzględnieniem kontekstu przepisu i celu rozporządzenia, w oderwaniu od wykładni nadawanej pojęciu w prawie krajowym oraz znaczenia nadawanego temu pojęciu w aktach unijnych z innych dziedzin prawa. Trybunał podkreśla „faktyczny charakter” pojęcia zwykłego pobytu oraz podaje okoliczności, które należy uwzględnić w celu ustalenia, że pobyt dziecka ma charakter zwykły. Należą do nich: fizyczna obecność dziecka, trwałość pobytu, zgodność z prawem pobytu, warunki oraz motywy pobytu dziecka na terytorium danego państwa członkowskiego, stosunki rodzinne i społeczne, miejsce uczęszczania do szkoły, znajomość języków, jak również obywatelstwo dziecka. W sprawach dotyczących odpowiedzialności rodzicielskiej nacisk jest położony na aspekt „jakościowy”. Siła powiązań ma świadczyć o integracji dziecka w środowisku społecznym i rodzinnym ${ }^{21}$, pozwalającej na określenie tego miejsca jako centrum życiowego dziecka. Należy zatem dokonać oglądu całokształtu sytuacji dziecka.

Trybunał podkreśla, że okoliczności te moga posiadać różną wagę w zależności od stanu faktycznego, w tym np. wieku dziecka. Gdy dziecko jest niemowlęciem, dzieli zazwyczaj środowisko społeczne i rodzinne osób, które się nim faktycznie zajmują. Istotne są zatem również okoliczności dotyczące osób sprawujących opiekę, takie jak: długość, regularność, warunki i przyczyny pobytu opiekuna w danym państwie oraz

${ }^{20}$ Wyr. Trybunału z dnia 2 kwietnia 2009 r. w sprawie A, C-523/07, http://curia. europa.eu.

${ }_{21}$ Zob. pkt 60 wyr. Trybunału z dnia 15 lutego 2017 r. w sprawie W, V przeciwko X, C-499/15, http://curia.europa.eu; pkt. 44-49 wyr. Trybunału z dnia 22 grudnia $2010 \mathrm{r}$. w sprawie Barbara Mercredi przeciwko Richardowi Chaffe'owi, C-497/10 PPU, http://curia. europa.eu. Zob. A. Richez-Pons: La notion de „résidence”. In: Le nouveau droit communautaire du divorce et de la responsabilité parentale. Eds. H. Fulchiron, C. Nourissat. Dalloz 2005, s. 155-156. 
pochodzenie geograficzne i rodzinne tej osoby ${ }^{22}$. Trybunał podkreślił ponadto konieczność jednolitej wykładni pojęcia na potrzeby ustalenia jurysdykcji w sprawach odpowiedzialności rodzicielskiej oraz o uprowadzenie i powrót dziecka ${ }^{23}$.

Katalog okoliczności wskazanych przez Trybunał ma charakter otwarty. Ciężar doboru okoliczności i ich wyważenia na gruncie konkretnej sprawy spoczywa zatem na sądach.

Orzecznictwo sądów krajowych, opinie rzeczników generalnych i wyroki samego Trybunału pokazuja, że swoboda pozostawiona przy ustalaniu miejsca zwykłego pobytu skutkuje różną oceną tych samych przypadków. Zróżnicowanie oceny może wynikać z przyznania jednej z okoliczności szczególnej wagi lub jej pominięcia. Do zagadnień, które budzą dyskusję, należą rola zamiaru i stanowiska rodziców lub opiekunów co do miejsca pobytu dziecka oraz możliwość ustalenia miejsca zwykłego pobytu w państwie, w którym dziecko nigdy nie było, np. w sytuacji, gdy narodziny dziecka nastapiły w miejscu, które nie było miejscem, w którym zgodnie z planami rodziców lub jednego z nich poród miał nastąić, lub w którym rodzice $\mathrm{z}$ dzieckiem planowali po porodzie zamieszkać.

\section{Wykładnia pojęcia miejsce zwykłego pohytu w najnowszym orzecznictwie Trybunału Sprawiedliwości (UE)}

\subsection{Wyrok z dnia 28 czerwea 2018 r. w sprawie C-512/17}

Orzeczenie wydane w sprawie $H R$ przy udziale KO $i$ Prokuratury Rejonowej Poznań-Stare Miasto w Poznaniu (C-512/17) w odpowiedzi na pytanie Sądu Rejonowego w Poznaniu ${ }^{24}$ potwierdza, że na gruncie rozporządzenia Bruksela II bis zamiar rodzica w kwestii miejsca zwykłego pobytu dziecka nie może stanowić sam w sobie czynnika determinujacego. Trybunał powiązał miejsce zwykłego pobytu dziecka z miejscem, gdzie faktycznie znajduje się centrum życiowe dziecka, a nie z miejscem,

${ }^{22}$ Zob. pkt. 52-56 wyr. w sprawie C-497/10 PPU.

${ }^{23}$ Punkt 41 wyr. Trybunału z dnia 8 czerwca 2017 r. w sprawie OL przeciwko PQ, C-111/17 PPU, http://curia.europa.eu.

${ }^{24}$ Wyrok Trybunału z dnia 28 czerwca 2018 r. w sprawie HR przy udziale: KO, Prokuratury Rejonowej Poznań-Stare Miasto w Poznaniu, C-512/17, http://curia.europa.eu. 
w którym dziecko ma zamieszkiwać zgodnie z zamiarem rodzica faktycznie sprawującego pieczę. Sprawa dotyczyła dziecka Polki i Belga. Para poznała się w Belgii w 2013 r. W czerwcu 2014 r. para zamieszkała wspólnie w Brukseli i w tym mieście w kwietniu 2015 r. urodziło się dziecko. Matka pozostawała zatrudniona na okres nieokreślony jako urzędniczka unijnej służby dyplomatycznej. Od chwili narodzin dziecka matka wielokrotnie przebywała z dzieckiem w Polsce w okresie urlopu rodzicielskiego, wakacji i świąt. Niektóre pobyty trwały kilka miesięcy. Po ponad roku od narodzin dziecka para rozstała się i matka postanowiła przenieść się na stałe z powrotem do Polski, gdzie posiadała własne mieszkanie. Matka wniosła do poznańskiego sądu o ustalenie miejsca zamieszkania dziecka przy niej. Sąd Rejonowy w Poznaniu stwierdził jednak brak jurysdykcji i odrzucił wniosek. Sąd Okręgowy w Poznaniu uchylił to postanowienie i przekazał sprawę do ponownego rozpoznania, wskazując, że dziecko miało miejsce zwykłego pobytu w Polsce. W ocenie sądu odwoławczego przemawiały za tym okoliczności, że dziecko w Belgii nie uczęszczało do żłobka, było wychowywane w kulturze polskiej, środowisko dziecka tworzyła głównie matka i jej rodzina, dziecko nie było zintegrowane ze środowiskiem belgijskim, a jego kontakty w tym zakresie były ograniczone do kontaktów z ojcem. Pierwsze pytanie prejudycjalne, z którym Sąd Rejonowy zwrócił się do Trybunału, dotyczyło wyważenia z jednej strony powiązań kulturowych i rodzinnych z państwem pochodzenia rodzica sprawującego na co dzień pieczę nad dzieckiem (w tym posługiwanie się przez dziecko językiem tego państwa), a z drugiej powiazań z państwem, w którym dziecko przebywa w pozostałych okresach, rodzic sprawujący głównie opiekę nad dzieckiem wykonuje pracę i w którym mieszka drugi rodzic utrzymujący regularne kontakty z dzieckiem. W drugim pytaniu Sąd Rejonowy ujął wątpliwość, czy więzi z rodzicem, który sprawuje codzienną opiekę nad dzieckiem, należy nadać równe, czy też większe znaczenie niż powiązaniu z drugim rodzicem.

Trybunał stwierdził, że w tego rodzaju stanie faktycznym okoliczność, że dziecko zamieszkiwało początkowo z obojgiem rodziców, a następnie, po ich rozstaniu, rodzic sprawujący faktyczna pieczę nad dzieckiem nadal zamieszkuje tam z dzieckiem, kontynuuje pracę zawodowa, drugi z rodziców zaś utrzymuje stałe, regularne kontakty z dzieckiem wskazuje, że dziecko ma cały czas w tym państwie miejsce zwykłego pobytu. Nie moga tutaj przeważyć okolicznościowe, nawet wydłużone pobyty w państwie pochodzenia dziecka, pochodzenie rodzica rzutujące na więzy kulturowe dziecka oraz ewentualny zamiar rodzica, aby w przyszłości osiedlić się z dzieckiem w państwie pochodzenia ${ }^{25}$.

\footnotetext{
${ }^{25}$ Punkty 65 i 66 wyr. w sprawie C-512/17.
} 
Wywody Trybunału pozwalają na sformułowanie ogólnego wniosku, że powiązania dotyczące ścisłego kręgu rodzinnego obejmującego dziecko i osoby, którym przysługuje władza rodzicielska, mają większą wagę niż względy kulturowe. Jeżeli te powiązania rodzinne prowadzą do jednego państwa, w którym skupia się codzienna egzystencja dziecka i opiekunów, to determinują one miejsce zwykłego pobytu dziecka. Powiązania te odpowiadaja kryterium bliskości z państwem mającym sprawować jurysdykcję. Względy kulturowe, w tym język i kontakty z dalszą rodziną, nie moga wówczas przejać roli czynników decydujących ${ }^{26}$.

Należy podkreślić, że w omawianej sprawie zamiar pozostał niezrealizowany. Przeprowadzka nie doszła do skutku. Wola jednego z rodziców zmiany miejsca pobytu dziecka może zostać uwzględniona, o ile zostanie urzeczywistniona, tak jak się to stało w sprawie C-497/10 $\mathrm{PPU}^{27}$. Stanowisko Trybunału zalecające dokonanie oceny całokształtu okoliczności w celu ustalenia centrum życiowego dziecka wpisuje się w tzw. model mieszany ustalania miejsca zwykłego pobytu dziecka. Został on wyodrębniony $\mathrm{w}$ doktrynie, obok tzw. parental intention model i independent/child centered model, na gruncie Konwencji haskiej z 1980 r. w sprawach o bezprawne zatrzymanie lub uprowadzenie dziec$\mathrm{ka}^{28}$. W orzecznictwie państw konwencyjnych prezentowane było bardzo zróżnicowane podejście ${ }^{29}$. W doktrynie przeciwstawiono dwa skrajne modele: parental intention model, w którym czynnik determinujący stanowi wola rodziców sprawujących władzę rodzicielską i jedno z rodziców nie może samowolnie doprowadzić do zmiany miejsca zwykłego pobytu dziecka, oraz independent/child centered model, w którym decydująca rolę maja związki pomiędzy dzieckiem a danym państwem, w którym może ono przebywać bez zgody opiekuna prawnego ${ }^{30}$. Model pośredni zaś to model, w którym centrum interesów dziecka jest ustalane z uwzględnieniem wielu okoliczności, w tym zamiarów rodziców

${ }^{26} \mathrm{~W}$ doktrynie niemieckiej podkreślono, że Trybunał odwołał się do znanych na gruncie praw krajowych zabiegów konkretyzacji klauzul generalnych. U.P. Gruber: Der gewöhnliche Aufenthalt von Säuglingen und Kleinkindern. „Praxis des Internationalen Privat- und Verfahrensrechts" 2019, H. 3, s. 220—221.

${ }_{27}$ Zob. wyr. Trybunału z dnia 22 grudnia 2010 r. w sprawie Barbara Mercredi przeciwko Richardowi Chaffe'owi, C-497/10 PPU.

${ }^{28}$ Podział przedstawiła R. Schuz: The Hague Child Abduction Convention: A Critical Analysis. Hart Publishing 2014, s. 186 i n.

${ }^{29}$ Orzeczenia sa publikowane w bazie orzeczeń prowadzonej przez Stałe Biuro Haskiej Konferencji The International Child Abduction Database - INCADAT, www.incadat.com. Zob. ponadto P.R. Beaumont, P.E. MacEleavy: The Hague Convention on International Child Abduction. Oxford University Press 1999, s. 88-113.

${ }^{30}$ Zob. R. Schuz: The Hague Child Abduction Convention..., s. 186 i n. 
sprawujących władzę rodzicielska ${ }^{31}$. Konsekwentne stanowisko Trybunału może oddziaływać na orzecznictwo sądów państw członkowskich i wykładnię pojęcia zwykłego pobytu, co jest pożądane, biorąc pod uwagę sprzężenie rozporządzenia i konwencji w sprawach o bezprawne uprowadzenie lub zatrzymanie dziecka.

$\mathrm{W}$ doktrynie niemieckiej trafnie zauważono, że orzeczenie w sprawie C-512/17 ma duże znaczenie praktyczne dla rozstrzygania spraw dotyczących rodzin imigrantów, które kultywują język i kulturę państwa pochodzenia, i których integracja społeczna i kulturowa w państwie zamieszkania może przebiegać powoli. Główne znaczenie ma lokalizacja powiązań rodzinnych dziecka i osób sprawujących opiekę. Odmienne założenie prowadziłoby zaś do „scementowania nieudanej integracji” ${ }^{32}$.

\subsection{Wyrok z dnia 17 października 2018 r. w sprawie C-393/18 PPU}

Bardziej kontrowersyjnego zagadnienia dotyczy wyrok Trybunału z dnia 17 października 2018 r. w sprawie UD przeciwko XB (C-393/18 PPU) ${ }^{33}$. To kolejna sprawa, w której pojawił się dylemat, czy możliwe jest ustalenie miejsca zwykłego pobytu dziecka w państwie, z którym łącza dziecko silne powiązania rodzinne, ale w którym dziecko nigdy nie było. Jest to jednak pierwsza sprawa, w której problem ten został poddany głębszej analizie, a Trybunał zajął jednoznaczne stanowisko.

Odpowiedź pozytywna oznaczałaby, że może istnieć grupa przypadków, w których fizyczna obecność nie zawsze stanowi element konieczny do stwierdzenia miejsca zwykłego pobytu. Taka możliwość jest brana pod uwage $\mathrm{w}$ doktrynie $\mathrm{w}$ przypadkach ustalania pierwszego miejsca zwykłego pobytu dziecka ${ }^{34}$. Sytuacje te są zróżnicowane. Poród może nastapić w państwie innym niż państwo zamieszkania rodziców - np. podczas urlopu lub podróży służbowej matki, albo gdy matka znajduje się

${ }^{31} \mathrm{Na}$ zmianę kierunku wykładni z parental intention model $\mathrm{w}$ stronę modelu mieszanego w orzecznictwie sądów angielskich wskazuja P. Beaumont, J. Holliday: Recent developments on the meaning of „habitual residence” in alleged child abduction cases, s. 4, https://abdn.pure.elsevier.com/en/publications/recent-developments-on-themeaning-of-habitual-residence-in-alleg.

${ }^{32}$ U.P. Gruber: Der gewöhnliche Aufenthalt..., s. 220.

${ }^{33}$ Wyr. Trybunału z dnia 17 października 2018 r. w sprawie UD przeciwko XB, C-393/18, www.curia.europa.eu.

${ }^{34}$ Zob. J. Kropholler: Internationales Privatrecht: einschließlich der Grundbegriffe des Internationalen Zivilverfahrensrechts. Tübingen, Mohr Siebeck, 2006, s. 283; U.P. Gruber: Der gewöhnliche Aufenthalt..., s. 220, przyp. 29 i powołana tam literatura. 
w tym innym państwie wbrew swojej woli, w sytuacji przymusu ${ }^{35}$. Problem powstaje, gdy potrzeba rozstrzygnięcia o losach dziecka zachodzi zanim znajdzie się ono $\mathrm{w}$ państwie docelowym, co może wynikać z konfliktu między rodzicami, lub dziecko z innych powodów nie może zostać przewiezione do państwa docelowego. Przyczynek do dyskusji stanowia sprawy rozpoznawane przed sądami angielskimi, dotyczace dzieci urodzonych $\mathrm{w}$ aranżowanych małżeństwach (zawieranych m.in. przez osoby pochodzace z Bangladeszu i Pakistanu) przez matki zatrzymane siła podczas wizyt rodzinnych $\mathrm{w}$ tych państwach ${ }^{36}$. Pytanie prejudycjalne dotyczące fizycznej obecności jako przesłanki ustalenia miejsca zwykłego pobytu było zatem kwestią czasu.

W wyroku z dnia 17 października 2018 r. Trybunał jednoznacznie uznał fizyczną obecność dziecka za warunek konieczny do stwierdzenia miejsca zwykłego pobytu dziecka w danym państwie. We wcześniejszych orzeczeniach okoliczność ta była ujmowana jako element podlegający uwzględnieniu, nie została natomiast określona wprost jako „przesłanka”. W wyroku w sprawie $A$ (C-523/07) Trybunał wskazał wprawdzie, że „poza fizyczną obecnością dziecka na terytorium państwa członkowskiego, należy uwzględnić inne czynniki”, jednak wypowiedź ta miała na celu podkreślenie, że sama fizyczna obecność nie jest wystarczająca do ustalenia zwykłego pobytu, ważny jest bowiem również charakter pobytu. W wyroku wydanym w 2017 r. w sprawie $W$, V przeciwko X (C-499/15) stwierdzono, że ustalenie miejsca zwykłego pobytu dziecka w danym państwie członkowskim wymaga co najmniej fizycznej obecności dziecka w tym państwie ${ }^{37}$. Sprawa ta dotyczyła jednak miejsca zwykłego pobytu starszego dziecka i nie towarzyszyły jej nadzwyczajne okoliczności. Spór kompetencyjny pomiędzy sądami litewskimi i holenderskimi dotyczył sytuacji, w której dziecko od piątego roku życia bezspornie zamieszkiwało z matka w Holandii, natomiast na Litwie (gdzie zamieszkiwał ojciec) dziecko nigdy nie było. Jedynym związkiem dziecka z Litwą było obywatelstwo litewskie, co nie wystarczało do uznania, że dziecko to ma w tym państwie miejsce zwykłego pobytu ${ }^{38}$.

Odpowiedź na pytanie, czy fizyczna obecność stanowi warunek konieczny do uznania, że dziecko ma w danym państwie miejsce zwykłego pobytu, próbował uzyskać sąd grecki w sprawie $O L$ przeciwko $P Q$

${ }_{35}$ Zob. zdanie odrębne Lorda Hughes do wyr. Supreme Court of the United Kingdom (Sądu Najwyższego Zjednoczonego Królestwa) z dnia 9 września 2013 r. In the Matter of A (Children) ([2013] UKSC 60, pkt 92); opinia Rzecznika Generalnego w sprawie C-393/18 PPU z dnia 20 września 2018 r.

${ }^{36}$ Zob. P. Beaumont, J. Holliday: Recent developments on the meaning...

${ }^{37}$ Punkt 61 wyr. z dnia 15 lutego 2017 r. w sprawie C-499/15, www.curia.europa.eu.

38 Punkt 63 wyr. w sprawie C-499/15. 
(C-111/17 PPU), w której Trybunał wydał wyrok dnia 8 czerwca 2017 r. ${ }^{39}$ Dotyczyła ona ustalenia miejsca zwykłego pobytu dziecka urodzonego w Grecji - państwie pochodzenia matki. Do ósmego miesiąca ciąży matka mieszkała z mężem we Włoszech. Para ustaliła, że matka przeniesie się do Grecji, gdzie w czasie porodu będzie przebywała pod opieka rodziny, i po pewnym czasie powróci do Włoch. Ojciec dziecka przyjechał na czas porodu do Grecji, a następnie wrócił do Włoch. Matka miała zaś pozostać jeszcze kilka miesięcy w Grecji. Po upływie tego okresu matka sama podjęła decyzję, że nie wróci do Włoch. Ojciec wystąpił do sądu włoskiego o rozwód, powierzenie mu wyłącznej pieczy nad dzieckiem i nakazanie powrotu dziecka do Włoch oraz zasądzenie alimentów od matki. Sądy włoskie stwierdziły brak jurysdykcji w sprawach odpowiedzialności rodzicielskiej oraz o alimenty, gdyż dziecko zamieszkuje w innym państwie. Równocześnie ojciec wystąpił przed sąd grecki z wnioskiem o powrót dziecka. Sąd grecki zwrócił się więc do Trybunału z pytaniami o wykładnię pojęcia miejsca zwykłego pobytu, gdy ze względów losowych lub z powodu siły wyższej dziecko urodziło się w innym państwie niż to, w którym rodzice wspólnie sprawują władzę rodzicielska, oraz czy fizyczna obecność stanowi warunek wstępny i konieczny do ustalenia miejsca zwykłego pobytu. Trybunał uznał, że dla rozstrzygnięcia sprawy odpowiedź w tym zakresie nie jest konieczna. Dziecko nie urodziło się bowiem w Grecji „ze względów losowych lub z powodu siły wyższej”. Trybunał przeformułował pytanie, aby rozstrzygnięcie dotyczyło kwestii, czy początkowy zamiar rodziców co do miejsca zwykłego pobytu dziecka $\mathrm{w}$ danym państwie może mieć charakter rozstrzygający niezależnie od okoliczności, że dziecko w tym państwie nigdy wcześniej nie było. W ocenie Trybunału znaczenie zamiaru rodziców zależy od okoliczności sprawy. Biorąc pod uwagę, że dziecko urodziło się w Grecji i tam przebywało, zgodnie z wolą obojga rodziców, bez przerwy przez kilka miesięcy, nie można za czynnik rozstrzygający uznać zarówno wcześniejszych planów rodziców co do powrotu matki z dzieckiem do Włoch, gdzie oboje rodzice mieli wcześniej miejsce zwykłego pobytu, jak również braku zgody ojca na dalsze pozostawanie dziecka w Grecji ${ }^{40}$.

W świetle wywodów na temat zamiarów rodziców można przypuszczać, że gdyby Trybunał zdecydował się na odpowiedź, to przyjąłby obecność na terytorium danego państwa jako warunek konieczny.

Rzecznik Generalny Nils Wahl w poprzedzającej wyrok opinii w ramach ogólnych rozważań nad wykładnią pojęcia zwykłego pobytu wyraźnie natomiast zasugerował, że nie można wykluczyć zaistnienia zupełnie

\footnotetext{
39 http://curia.europa.eu.

${ }^{40}$ Punkty 50-51 wyr. Trybunału w sprawie OL przeciwko PQ, C 111/17 PPU.
} 
wyjątkowych okoliczności, w których można odstąić od kryterium fizycznej obecności przy ustalaniu miejsca zwykłego pobytu ${ }^{41}$.

Konkretne stanowisko, uzasadnione szerszymi wywodami w postaci zarówno opinii Rzecznika Generalnego Henrika Saugmandsgaarda, jak i wyroku Trybunału, przyniosła sprawa C-393/18, w której pytanie złożył angielski High Court of Justice. Wnioski opinii i wyroku sa jednak odmienne. Angielski sąd powziął wattpliwość co do możliwości ustalenia w Zjednoczonym Królestwie miejsca zwykłego pobytu dziecka urodzonego w Bangladeszu i przebywającego tam od roku. Rodzice dziecka, obywatel brytyjski i obywatelka Bangladeszu, zawarli aranżowany ślub w Bangladeszu w $2013 \mathrm{r}$. W połowie 2016 r. małżonkowie przybyli do Zjednoczonego Królestwa z zamiarem, jak utrzymywała matka, zamieszkania tam. Pod koniec 2016 r. małżonkowie udali się do Bangladeszu. Wizyta miała mieć charakter tymczasowy. Według kobiety, mąż zatrzymał ją jednak wbrew jej woli w tym państwie. Dziecko urodziło się w lutym 2017 r. i od tego czasu pozostawało z matką cały czas w Bangladeszu. Matka wszczęła postępowania $\mathrm{w}$ sprawie odpowiedzialności rodzicielskiej przed angielskim sądem, domagając się zarządzenia powrotu jej i dziecka do Zjednoczonego Królestwa. High Court of Justice zwrócił się w związku z tym do Trybunału z pytaniem prejudycjalnym, czy fizyczna obecność dziecka w danym państwie stanowi element konieczny do ustalenia miejsca zwykłego pobytu w rozumieniu art. 8 rozporzadzenia Bruksela II bis, oraz czy dla odpowiedzi na to pytanie może mieć znaczenie, że nieobecność dziecka i matki wynika z przymusu stosowanego przez ojca. Sąd angielski odwołał się do praw człowieka przynależnych matce lub dziecku zgodnie z art. 3 i 5 Europejskiej konwencji praw człowieka i podstawowych wolności, przewidującymi zakaz tortur i poniżającego traktowania oraz prawo do wolności.

W rozważania na temat wykładni pojęcia zwykłego pobytu została zatem włączona kwestia ochrony praw człowieka, a pytanie dotyczyło możliwości pominięcia elementu fizycznej obecności w Zjednoczonym Królestwie w sytuacji, gdy nieobecność jest wynikiem działań osób trzecich naruszających prawa człowieka.

W opinii z dnia 20 września 2018 r. Rzecznik Generalny H. Saugmandsgaard stwierdził, że fizyczna obecność dziecka na terytorium państwa członkowskiego nie stanowi warunku wstępnego dla określenia miejsca zwykłego pobytu w tym państwie. W ocenie Rzecznika takiego podejścia wymaga kryterium bliskości oraz nadrzędny interes dziecka. Stanowisko zgodne $\mathrm{z}$ opinią rzecznika przedstawiły $\mathrm{w}$ toku postępowania rządy Wielkiej Brytanii i Republiki Czeskiej.

${ }^{41}$ Punkt 81 opinii Rzecznika Generalnego N. Wahla w sprawie C 111/17 PPU OL przeciwko $\mathrm{PQ}$. 
Rzecznik poddał analizie różne scenariusze. Jako przykład przemawiający za odstąpieniem od wymogu fizycznej obecności wskazał sytuację, gdy dziecko pary zamieszkującej w Niemczech urodzi się przedwcześnie podczas urlopu we Francji. Dziecko powinno mieć przypisane miejsce zwykłego pobytu w Niemczech od chwili narodzin. W przeciwnym razie należałoby przyjąć, że dopóki nie zostanie przywiezione do Niemiec nie posiada miejsca zwykłego pobytu, bo trudno za takie uznać terytorium Francji, z którym rodzina nie jest w żaden sposób związana. Zasadne jest natomiast oczekiwanie, że $\mathrm{w}$ takim przypadku sądy niemieckie sprawuja jurysdykcję ${ }^{42}$. Narodziny poza miejscem zamieszkania rodziny nie oznaczaja, że sytuacja nie może ulec zmianie, gdy dziecko pozostanie w miejscu, w którym się urodziło, i nawiąże związki społeczne i kulturowe w miejscu pobytu kosztem związków z miejscem, z którym miało być zintegrowane ${ }^{43}$.

Rzecznik akceptuje, że rezultatem pozostawienia marginesu swobody oceny jest ryzyko niejednolitych rozstrzygnięć przez sądy krajowe w podobnych przypadkach. Jest to „cena” realizacji zasady bliskości, wyrażonej w integracji dziecka ze środowiskiem społecznym i rodzinnym ${ }^{44}$. Okoliczność, że narodziny dziecka nastapiły w danym państwie z powodu przymusu zastosowanego przez ojca dziecka, potencjalnie z naruszeniem praw podstawowych matki i dziecka, stanowi istotny element w ramach ustalania „warunków i powodów pobytu”. Jak wskazał Rzecznik, przymusowy i niepewny pobyt matki nie odznacza się stabilnością i regularnością wiązaną z pojęciem zwykłego pobytu. Przyjęcie jednak, że dziecko ma miejsce zwykłego pobytu w państwie, w którym zgodnie z wolą matki miało się urodzić, wymagałoby ustalenia, że matka miała rzeczywiście w tym państwie miejsce zwykłego pobytu. Ocenę tę Rzecznik pozostawił sądowi odsyłającemu ${ }^{45}$.

Rzecznik Generalny zaakceptował zatem ustalenie miejsca zwykłego pobytu w państwie, w którym dziecko nigdy nie było, ale z którym łącza je bliskie związki nie tylko w sytuacji, gdy nieobecność wynika z celowych, bezprawnych działań innych osób, lecz również w sytuacjach losowych. Trybunał zajął odmienne stanowisko, które podziela również Komisja Europejska, przyjmując, że dziecko musi być fizycznie obecne w państwie członkowskim, aby uznać, że posiada tam miejsce zwykłego pobytu. Fizyczna obecność ma stanowić warunek wstępny, konieczny, który uzasadnia dopiero badanie trwałości obecności w danym

${ }^{42}$ Zob. pkt. 71 i 78 opinii w sprawie C-393/18.

${ }_{43}$ Zob. pkt 71 opinii w sprawie C-393/18.

${ }_{44}$ Punkt 76 opinii w sprawie C-393/18.

${ }^{45}$ Punkt 97 opinii w sprawie C-393/18. 
państwie ${ }^{46}$. Oceny tej nie zmieniłyby ustalenia, że dziecko urodziło się w innym miejscu niż planowała matka wskutek przymusu zastosowanego przez ojca. Zamiary rodzica sprawującego pieczę nad dzieckiem i jego miejsce zwykłego pobytu stanowią element, który podlega ocenie, ale nie można nadać im szczególnego znaczenia ${ }^{47}$. Taka wykładnia jest, zdaniem Trybunału, zgodna z kryterium bliskości, na które nacisk kładzie rozporządzenie Bruksela II bis; względy na dobro dziecka i ochrona najlepszego interesu dziecka nie wymagaja „wykraczania poza ramy pojęcia zwykłego pobytu" 48 .

Oba stanowiska podkreślają zatem rolę kryterium bliskości z określonym porządkiem prawnym $\mathrm{w}$ procesie ustalania miejsca zwykłego pobytu. Rzecznik Generalny uznaje jednak, że bliskość w sensie geograficznym może całkowicie ustąić wobec siły powiązań ze środowiskiem społecznym i rodzinnym innego państwa. Trybunał natomiast uważa, że oba zasadnicze elementy pojęcia, tj. pobyt rozumiany jako fizyczna obecność oraz kwalifikacja pobytu jako „zwykłego”, muszą zostać poddane analizie pod względem kryterium bliskości. W przypadku pierwszego z określeń minimalny wymóg w postaci fizycznej obecności musi zostać spełniony. W ramach badania stabilności sytuacji analizie zostana poddane dalsze okoliczności, w tym okres pobytu i powiązania rodzinne.

\section{Podsumowanie}

Trybunał Sprawiedliwości słusznie wskazał na granice wykładni pojęcia zwykłego pobytu. Pozostawienie pewnej swobody w ustalaniu miejsca zwykłego pobytu w okolicznościach konkretnej sprawy można uznać za atut tego kryterium. Ta swoboda nie może jednak prowadzić do wypaczenia istoty pojęcia zwykłego pobytu. Przypisanie dziecku miejsca zwykłego pobytu w przypadkach wskazywanych przez Rzecznika oznaczałoby w istocie przyjęcie dla dziecka konstrukcji miejsca zwykłego pobytu pochodnego od miejsca zwykłego pobytu rodziców. Tego rodzaju powiązania, które może prowadzić do państwa, z którym dziecko nie jest realnie związane, chciano właśnie uniknąć, przyjmując kryterium zwykłego pobytu w konwencjach haskich na początku XX w. Zwolennicy odstąpienia od wymogu fizycznej obecności odżegnuja się od takiego po-

46 Punkty 52-53 wyr. w sprawie C-393/18.

${ }_{47}$ Punkty 60-61 wyr. w sprawie C-393/18.

48 Punkt 68 wyr. w sprawie C-393/18. 
równania, wskazujac, że przypisanie dziecku miejsca zwykłego pobytu jest wówczas wynikiem analizy okoliczności świadczących o integracji z tym miejscem rodziny dziecka ${ }^{49}$ i, o ile rzeczywiście można przyjąć, że powiązanie $\mathrm{z}$ danym państwem nie byłoby fikcyjne, to jednak pominięcie okoliczności faktycznej dotyczącej jedynie dziecka, tj. tego, gdzie dziecko się fizycznie znajduje, oznacza jawne zanegowanie faktycznego charakteru pojęcia zwykłego pobytu i znaczenia nazwy „pobyt”. Podstawa łacznika stawałaby się przynależność do wspólnoty rodzinnej i społecznej. Do tej pory elastyczne podejście do ustalenia miejsca zwykłego pobytu było realizowane przez wykładnię określenia „zwykły”. W celu realizacji kryterium bliskości za zwykły może zostać uznany już bardzo krótki okres pobytu, jak np. przyjął Trybunał w sprawach dotyczących noworodków i małych dzieci. Taka sytuacja może również następować zaraz po przeprowadzce do innego państwa, gdy okoliczności sprawy wskazują na powstawanie powiązań z nowym miejscem pobytu przy jednoczesnym ustaniu powiązań z poprzednim miejscem pobytu. Charakter pobytu odzwierciedlają wówczas okoliczności dotyczące osób sprawujących opiekę nad dzieckiem potwierdzających przeprowadzkę i wolę pozostania w nowym miejscu przez dłuższy okres (podjęcie pracy przez rodzica, umieszczenie dziecka w placówce edukacyjnej).

Tego rodzaju zabiegi nadwyrężają oczywiście przyjęte „u zarania” w pracach Haskiej Konferencji założenie, że pojęcie zwykłego pobytu ma charakter czysto faktyczny (notion de fait). Rzecznik proponuje jednak objęcie nazwą „zwykły pobyt” przypadków obejmujących bliskie związki, a niekoniecznie sam pobyt. Lokalizacja powiązań ze wspólnota rodzinna i społeczną miałaby zatem pozwolić na pominięcie w wykładni pojęcia zwykłego pobytu literalnego znaczenia nazwy „pobyt”.

Warto też zauważyć, że chociaż pominięcie elementu fizycznej obecności miałoby nastapić tylko w sytuacjach nadzwyczajnych, ocena, czy dana sprawa do takiej kategorii się zalicza, zostałaby pozostawiona praktyce. Oprócz opisanych powyżej przypadków porodu w innym państwie z powodów losowych, siły wyższej lub przemocy zastosowanej wobec matki, za tego rodzaju sprawy mogłyby zostać uznane inne sytuacje, w których pojawiałby się argument dotyczacy przypadkowości lub przymusowości aktualnego pobytu, np. gdy dziecko urodziło się za granica zgodnie z planami rodziców (np. w wybranej zagranicznej placówce medycznej lub w celu uzyskania przez dziecko obywatelstwa, zgodnie z zasada iuris soli), a następnie $\mathrm{z}$ uwagi na stan zdrowia lub przeszkody imigracyjne nie może zostać przewiezione do państwa zamieszkania rodziców. W sytuacji przymusowej znajdują się uchodźcy i migranci ekono-

${ }_{49}$ Zob. zdanie odrębne sędziego Lorda Hughes, pkt 92 orzeczenia In the Matter of A. 
miczni. Analogicznie do argumentacji przytoczonej w sprawie C-393/18 jako argument za przypisaniem w państwie pochodzenia rodziców miejsca zwykłego pobytu dziecka urodzonego w zamkniętym ośrodku mogłaby zostać powołana przymusowa nieobecność w państwie pochodzenia z powodu działań wojennych lub prześladowań ${ }^{50}$.

Z perspektywy polskiej praktyki warto zauważyć, że stanowisko zakładające ustalenie w pierwszej kolejności miejsca pobytu, a następnie okoliczności, które moga charakteryzować ten pobyt jako zwykły, znajduje odzwierciedlenie w orzecznictwie sądów polskich. Sąd Okręgowy we Włocławku w postanowieniu z 2009 r. wskazał, że „przebywanie na terytorium określonego państwa wówczas można zakwalifikować jako »zwykły pobyt", gdy dana osoba ma w nim swoje centrum życiowe”, odrzucając utożsamianie pojęć „miejsca zwykłego pobytu” i „miejsca zamieszkania” w rozumieniu art. 25 k.c. i n., w tym możliwość stosowania konstrukcji zamieszkania pochodnego ${ }^{51}$. Sąd ten podkreślił również zminimalizowanie elementu intencjonalnego i zobiektywizowaną ocenę całokształtu danej sytuacji życiowej ${ }^{52}$. Sądom polskim nie jest także obce elastyczne podejście do określenia pobytu jako zwykłego. Jak już wskazano, za pobyt

${ }^{50}$ Rozporządzenie w art. 13 ust. 2, podobnie jak konwencja haska z 1996 r. w art. 6 ust. 1, przewiduje w przypadku dzieci będących uchodźcami jurysdykcję opartą na pobycie dziecka. Celem tego przepisu jest wskazanie podstawy jurysdykcji dla dzieci, których więzy z miejscem poprzedniego miejsca zwykłego pobytu zostały zerwane, a pobyt w państwie, w którym dziecko się znajduje, z uwagi na niepewną sytuację dziecka, nie może zostać uznany za zwykły. Zob. P. Lagarde: Explanatory Report on the 1996 Hague Child Protection Convention..., s. 555.

${ }^{51} \mathrm{~W}$ orzecznictwie sądów polskich odnotowano przypadki utożsamiania miejsca zwykłego pobytu z miejscem zamieszkania. Zob. uwagi na gruncie rozporządzenia nr 4/2009 A. Frąckowiak-Adamska, A. Guzewicz, Ł. Petelski: Skuteczność stosowania przez sqdy polskie unijnych rozporzadzeń: $n r$ 44/2001, nr 2201/2003, nr 864/2007, nr 593/2008 i nr 4/2009. „Europejski Przegląd Sądowy” 2016, nr 10, s. 10. W opracowaniu tym, obejmującym podsumowanie przeglądu polskiego orzecznictwa m.in. pod względem prawidłowości stosowania unijnych rozporządzeń, wskazano, że w polskich sądach „wzrasta świadomość unijnego mechanizmu wykładni i przy określeniu pojęcia zwykłego pobytu dziecka sądy zaczynają odwoływać się do wykładni autonomicznej, której reguły prowadzą do rozumienia miejsca zwykłego pobytu jako centrum egzystencji”. Ibidem.

${ }^{52} \mathrm{~W}$ sprawie rozstrzygniętej post. Sądu Okręgowego we Włocławku z dnia 28 sierpnia 2009 r., sygn. akt V CZ 37/09, matka wniosła przed sąd polski o pozbawienie ojca władzy rodzicielskiej nad dzieckiem urodzonym w 2006 r. w Wielkiej Brytanii i tam od urodzenia przebywającym z matka. Matka twierdziła, że jej pobyt w Wielkiej Brytanii ma charakter jedynie zarobkowy, jej miejsce zwykłego pobytu zaś pozostaje w Polsce. Miejsce to należy utożsamiać z kodeksowym pojęciem miejsca zamieszkania i w rezultacie przypisać dziecku miejsce zamieszkania matki (art. 25-26 k.c.). Zob. „Przegląd Orzecznictwa Sądu Apelacyjnego w Gdańsku” 2010, nr 1, s. 75-86, LEX nr 563037. Zob. również post. Sądu Rejonowego w Inowrocławiu z dnia 22 lutego 2019 r., sygn. akt III Nsm 768/18. LEX nr 2797411. 
zwykły może zostać uznany pobyt bardzo krótki. Sąd Rejonowy w Zduńskiej Woli uznał swoją jurysdykcję w sprawie o pozbawienie władzy rodzicielskiej nad dwójką dzieci, która została wniesiona przez matkę przeciwko ojcu w tym samym miesiącu, w którym matka przeprowadziła się z dziećmi do Polski z Holandii, gdzie rodzina mieszkała przez kilka lat ${ }^{53}$.

Postawienie granicy wykładni pojęcia zwykłego pobytu w postaci wymogu fizycznej obecności nie wyklucza sprawowania jurysdykcji w sprawie dotyczącej odpowiedzialności rodzicielskiej przez państwo, w którym zlokalizowane sa powiązania rodzinne dziecka. Niemożność stwierdzenia miejsca zwykłego pobytu w tym państwie nie oznacza, że dziecko ma miejsce zwykłego pobytu w państwie, w którym się fizycznie znajduje. Jak podkreślił Trybunał, fizyczna obecność stanowi warunek wstępny. W dalszym ciagu ocenie będzie podlegać charakter pobytu, jego trwałośćc ${ }^{54}$ i konieczne będzie ustalenie powiązań świadczących o integracji dziecka z dana społecznością. $\mathrm{W}$ tego rodzaju sprawach, obejmujących przypadki nieplanowanego lub przymusowego porodu w innym państwie, prawdopodobne jest stwierdzenie, że dziecko w ogóle nie posiada miejsca zwykłego pobytu. Jurysdykcja może zostać wówczas oparta na łączniku pobytu $^{55}$. Pomiędzy państwami członkowskimi może wówczas dojść do przekazania jurysdykcji sądom państwa „lepiej umiejscowionego" ${ }^{56}$. Gdy dziecko przebywa w państwie trzecim, w braku jurysdykcji sądu innego państwa członkowskiego, podstawa jurysdykcji państwa „docelowego” może wynikać z prawa krajowego, na co wskazuje art. 14 rozporządzenia Bruksela II bis, np. na podstawie obywatelstwa. Przywołane mechanizmy pozwalaja na realizacje prawa do sądu i sprawowanie jurysdykcji przez sąd rzeczywiście bliższy sprawie. Ochrona interesów i praw dziecka może zatem nastąpić w inny sposób niż przez „sztuczna” wykładnię pojęcia zwykłego pobytu.

${ }^{53}$ Zob. post. Sądu Okręgowego w Sieradzu z dnia 25 lutego 2020 r., sygn. akt I Ca 598/19. LEX nr 2907127. Sąd Okręgowy nie uwzględnił zarzutu braku jurysdykcji krajowej, wskazując, że „Matka z dziećmi wróciła do kraju w maju 2018 r. z zamiarem stałego pobytu". Oceny tej nie zmienił fakt, że po pół roku matka z dziećmi przeprowadziła się z powrotem do Holandii, gdyż ,jej powtórny wyjazd do Holandii nastapił pod koniec grudnia 2018 r. z przyczyn, których w dacie przyjazdu nie przewidziała”.

${ }^{54}$ Punkt 53 wyr. w sprawie C-393/18.

55 Artykuł 13 rozporządzenia Bruksela II bis. Subsydiarny łącznik pobytu przewiduje również konwencja haska z $1996 \mathrm{r}$.

${ }^{56}$ Artykuł 15 rozporządzenia Bruksela II bis. W stosunkach między stronami konwencji haskiej z 1996 r. przekazanie może nastąić na podstawie przepisów konwencyjnych. 


\section{Bibliografia}

Actes de la Deuxième Conférence de la Haye. La Haye 1894.

Baetge D.: Der gewöhnliche Aufenthalt im Internationalen Privatrecht. Tübingen 1994.

Beaumont P.R., Holliday J.: Recent developments on the meaning of „habitual residence" in alleged child abduction cases, https://abdn.pure.elsevier.com/en/publications/recent-developments-on-the-meaning-of-habitualresidence-in-alleg.

Beaumont P.R., MacEleavy P.E.: The Hague Convention on International Child Abduction. Oxford University Press 1999.

Bobrzyńska O.: Zwykty pobyt w konwencjach Haskiej Konferencji Prawa Prywatnego Międzynarodowego. „Kwartalnik Prawa Prywatnego” 2019, z. 2, s. $417-466$.

Bucher A.: La famille en droit international prive. „Académie de Droit International de la Haye, Recueil des cours" 2000, T. 283, s. 9-186.

Frąckowiak-Adamska A., Guzewicz A., Petelski Ł.: Skuteczność stosowania przez sqdy polskie unijnych rozporzadzeń: nr 44/2001, nr 2201/2003, nr 864/2007, nr 593/2008 i nr 4/2009. „Europejski Przegląd Sądowy” 2016, nr 10 , s. $4-12$.

Gruber U.P.: Der gewöhnliche Aufenthalt von Säuglingen und Kleinkindern. „Praxis des Internationalen Privat- und Verfahrensrechts” 2019, H. 3, s. $217-221$.

Hoogstraten M.H. van: La codification par traités en droit international privé dans le cadre de la Conférence de la Haye. „Académie de Droit International de la Haye, Recueil des cours” 1969, T. 122 (1967 III), s. 337-425.

Kropholler J.: Internationales Privatrecht: einschließlich der Grundbegriffe des Internationalen Zivilverfahrensrechts. Tübingen, Mohr Siebeck, 2006.

Lagarde P.: Explanatory Report on the 1996 Hague Child Protection Convention. In: Proceedings of the Eighteenth Session (1996). T. 2. Protection of children, s. 533-605.

Mączyński A.: Statut personalny osób fizycznych. Refleksje „de lege lata” $i$ „de lege ferenda”. W: „Leges Sapere”. Studia i prace dedykowane Profesorowi Januszowi Sondlowi w pięćdziesiata rocznice pracy naukowej. Red. W. Uruszczak et al. Kraków 2008, s. 305-323.

Mostowik P.: Władza rodzicielska i opieka nad dzieckiem $w$ prawie prywatnym międzynarodowym. Kraków 2014.

Pilich M.: Eaczniki personalne osób fizycznych $w$ prawie prywatnym międzynarodowym (zagadnienia wybrane). „Problemy Prawa Prywatnego Międzynarodowego" 2016, T. 19.

Pilich M.: Zasada obywatelstwa $w$ prawie prywatnym międzynarodowym. Warszawa 2015. 
Richez-Pons A.: La notion de „résidence”. In: Le nouveau droit communautaire du divorce et de la responsabilité parentale. Eds. H. Fulchiron, C. Nourissat. Dalloz 2005, s. 149-156.

Schuz R.: The Hague Child Abduction Convention: A Critical Analysis. Hart Publishing 2014.

Steiger W. von: Rapport explicatif. In: Actes et documents de la Neuvième session (1960). T. 4. Protection des mineurs. La Haye 1961.

Świerczyński M., w: „System Prawa Prywatnego”. T. 20A: Prawo prywatne międzynarodowe. Red. M. Pazdan. Warszawa 2014.

Winter L.I. de: Nationality or domicile: the present state of affairs. „Académie de Droit International de la Haye, Recueil des cours” 1970, T. 128 (1969 III), s. $347-503$. 